\title{
SILAGE QUALITY OF CORN AND SORGHUM ADDED WITH FORAGE PEANUTS ${ }^{1}$
}

\author{
WALKÍRIA GUIMARÃES CARVALHO ${ }^{2}$, KÁTIA APARECIDA DE PINHO COSTA ${ }^{2 *}$, PATRÍCIA SOARES \\ EPIFANIO ${ }^{2}$, ROZANA CASTRO PERIM ${ }^{2}$, DANIEL AUGUSTO ALVES TEIXEIRA ${ }^{3}$, \\ LUCILENE TAVARES MEDEIROS ${ }^{3}$
}

\begin{abstract}
Corn and sorghum are standard silage crops because of their fermentative characteristics. While corn and sorghum silages have lower crude protein (CP) contents than other crops, intercropping with legumes can increase CP content. Furthermore, one way to increase CP content is the addition of legumes to silage. Consequently, the research objective was to evaluate the fermentative and bromatological characteristics of corn (Zea mays) and sorghum (Sorghum bicolor) silages added with forage peanuts (Arachis pintoi). The experimental design was completely randomized with four replicates. The treatments consisted of corn silage, sorghum silage, forage peanut silage, corn silage with 30\% forage peanut, and sorghum silage with $30 \%$ forage peanut. The results showed that the corn and sorghum added with peanut helped to improve the silage fermentative and bromatological characteristics, proving to be an efficient technique for silage quality. The forage peanut silage had lower fermentative characteristics than the corn and sorghum silages. However, the forage peanut silage had a greater CP content, which increased the protein contents of the corn and sorghum silages when intercropped with forage peanuts.
\end{abstract}

Keywords: Additive. Arachis pintoi. Sorghum bicolor. Zea mays.

\section{QUALIDADE DA SILAGEM DE MILHO E SORGO ADITIVADA COM AMENDOIM FORRAGEIRO}

RESUMO - O milho e o sorgo são considerados culturas padrão para ensilagem, em virtude de suas características fermentativas. No entanto, silagens de milho e sorgo apresentam teores de proteína bruta inferiores aos de outras culturas. E uma das formas para aumentar a proteína bruta é a adição de leguminosa na ensilagem. Diante disso, objetivou-se avaliar as características fermentativas e bromatológicas da silagem de milho (Zea mays) e sorgo (Sorghum bicolor) aditivada com amendoim forrageiro (Arachis pintoi). $\mathrm{O}$ delineamento experimental foi o inteiramente casualizado, com quatro repetições. Os tratamentos foram constituídos de silagem de milho; silagem de sorgo; silagem de amendoim forrageiro; silagem de milho com $30 \%$ de amendoim forrageiro e silagem de sorgo com $30 \%$ de amendoim forrageiro. Os resultados demonstraram que a silagem de milho e sorgo aditivada com amendoim forrageiro, contribuiu para melhorar os parametros fermentativos e bromatológicos da silagem, mostrando ser uma técnica eficiente para a qualidade da silagem. A silagem de amendoim forrageiro apresentou caracteríticas fermentantivas inferiores a silagem de milho e sorgo, em contrapartida apresentou maior teor de PB, que contribuiu para aumentar o teor protéico das silagens de milho e sorgo.

Palavras-chave: Aditivo. Arachis pintoi. Sorghum bicolor. Zea mays.

\footnotetext{
*Corresponding author

${ }^{1}$ Received for publication in 04/11/2014; accepted in 03/22/2016.

Paper extracted from the Masters' Thesis of the first author.

${ }^{2}$ Department of Animal Science, Instituto Federal Goiano, Campus Rio Verde, Rio Verde, GO, Brazil; katiazoo@hotmail.com, carvalho.zootecnia@gmail.com, patyepifanio@yahoo.com.br, rozana.perim@gmail.com.

${ }^{3}$ Department of Agricultural Sciences, Universidade de Rio Verde, Rio Verde, GO, Brazil; danielaugustoat6@hotmail.com, tavaresmedeiros@yahoo.com.
} 


\section{INTRODUCTION}

The Midwest Region has national prominence in forage that presents high grain production, with the potential for use in silage and in ruminant feed during the dry season (PINTO et al., 2012). Numerous forages can be used for this purpose, although the corn and sorghum crops are preeminent for silage with respect to growth, high productivity, and energy value (PAZIANI et al., 2009; PINHO et al., 2007).

Notably, among the desirable characteristics of corn silage, the soluble carbohydrate (CHOsol) levels found in plants lead to lactic fermentation, promoting the conservation of a highly nutritious food (OLIVEIRA et al., 2010). Sorghum is a promising culture and has been widely employed because it is an excellent choice in situations where drought and low soil fertility conditions pose greater risks to other cultures (SANTOS et al., 2009) and because it can produce more than one cut from a single seeding (CARDOSO et al., 2012). In addition to producing more than forage corn does, sorghum presents a lower production cost, in view of the lower consumption and price of the seed. The nutritive value of sorghum silage is usually equivalent to $85 \%$ to $90 \%$ of corn silage (PINHO et al., 2007).

However, despite the fact that corn and sorghum are considered standard for silage (because of their fermentative characteristics) and have a high digestibility and energy density, the silages of these grasses have lower crude protein (CP) levels compared with other cultures (PINTO et al., 2012), which is a limitation to its exclusive use in animal performance, especially for animals with high nutritional requirements.

Accordingly, a low CP silage content can be circumvented with the use of leguminous plants, which can contribute as alternatives for the protein enrichment of silage and supply it with a greater amount of calcium and phosphorus. This promising technology aims to reduce the cost of silage for livestock production during periods of low fodder supply (PAULINO et al., 2009; REZENDE et al., 2011).

The perennial peanut (Arachis pintoi) stands out among the pulses, presenting a good production of dry mass, a high nutritional value, persistence, the ability to establish and introduce nitrogen into the soil-plant system, excellent ground cover, adaptation to low-acid soils with average fertility, and the ability to be intercropped with various grasses in livestock farming system integration. In addition, the feed peanuts can be used for silage production with satisfactory nutritional outcomes such as high protein content $(21.60 \% \mathrm{CP})$ and low fiber content (NDF
$45.09 \%$ and $39.00 \%$ FDA), contributing as an additive for silage (PAULINO et al., 2009).

However, little is known about the quality of corn silage and sorghum with the addition of forage peanuts. Therefore, the research objective was to evaluate the fermentative and bromatological characteristics of corn (Zea mays) and sorghum (Sorghum bicolor) silages supplemented with forage peanuts (Arachis pintoi).

\section{MATERIAL AND METHODS}

The experiment was carried out under field conditions located at the $17^{\circ} 48^{\prime} \mathrm{S}$ latitude, $50^{\circ} 55^{\prime}$ $\mathrm{W}$ longitude and 748-m altitude at the Federal Institute of Goiás State, in the Municipality of Rio Verde, Goiás, from December 2011 to March 2012 in a Haplorthox (EMBRAPA, 2013).

The physical and chemical characteristics of the experimental soil area at $0-20 \mathrm{~cm}$ before planting were $347 \mathrm{~g} \mathrm{~kg}^{-1}$ clay; $255 \mathrm{~g} \mathrm{~kg}^{-1}$ silt; $398 \mathrm{~g}^{-1} \mathrm{~kg}$ sand; water pH: 5.4 ; $\mathrm{Ca}: 3.33 \mathrm{cmolc} \mathrm{dm}^{-3}$; $\mathrm{Mg}: 1.08 \mathrm{cmolc}$ $\mathrm{dm}^{-3} ; \mathrm{Al}: 0.05 \mathrm{cmolc} \mathrm{dm}^{-3} ; \mathrm{Al}+\mathrm{H}: 2.40 \mathrm{cmolc} \mathrm{dm}^{-3}$; $\mathrm{K}: 0.65$ cmolc dm $\mathrm{dm}^{-3}$; CTC: 7.46 cmolc $\mathrm{dm}^{-3}$; P: 3.8 $\mathrm{mg} \mathrm{dm}{ }^{-3}$; $\mathrm{Cu}: 3.03 \mathrm{mg} \mathrm{dm}^{-3}$; $\mathrm{Zn}: 15.42 \mathrm{mg} \mathrm{dm}^{-3}$; V: $67.83 \%$ and M.O: $21.10 \mathrm{~g} \mathrm{~kg}^{-1}$.

The area was formerly used for Brachiaria brizantha cv. Marandu. Glyphosate was applied at a dose of $580 \mathrm{~g} \mathrm{ha}^{-1}$ for desiccation. Twenty days after desiccation, the area was harrowed and leveled. Next, the experimental units were delineated. The area of each plot was $9 \mathrm{~m}^{2}$, being $3 \mathrm{~m}$ long $\times 3 \mathrm{~m}$ wide, with a total area of $45 \mathrm{~m}^{2}$.

Sowing was performed manually on December 17, 2011, when the soil moisture conditions were favorable. Single superphosphate was added during planting at $100 \mathrm{~kg} \mathrm{ha}^{-1}$ of $\mathrm{P}_{2} \mathrm{O}_{5}$.

The corn and sorghum seeds were sown at a depth of $5 \mathrm{~cm}$ with a spacing of $0.50 \mathrm{~m}$. In the intercropping systems, legume seeds were sown at $0.25 \mathrm{~m}$ between the corn or sorghum rows. In the single system, forage peanut seeds were planted at a depth of $3 \mathrm{~cm}$ with a spacing of $0.50 \mathrm{~m}$. The following crop varieties were cropped: Zea mays cv. Biogene BG7049H, Sorghum bicolor cv. CHOPPER Atlântica, and Arachis pintoi cv. Amarillo - Matsuda.

Thirty days after sowing, the corn and sorghum plots were manually side-dressed with urea and potassium chloride at $80 \mathrm{~kg}$ of nitrogen $\mathrm{ha}^{-1}$ and $60 \mathrm{~kg}$ of $\mathrm{K}_{2} \mathrm{O} \mathrm{ha}{ }^{-1}$, respectively. The single and intercropped forage peanut plots were side-dressed with $60 \mathrm{~kg}$ of $\mathrm{K}_{2} \mathrm{O} \mathrm{ha}^{-1}$.

Data on daily rainfall and average monthly temperature were monitored during the experiment (Figure 1). 


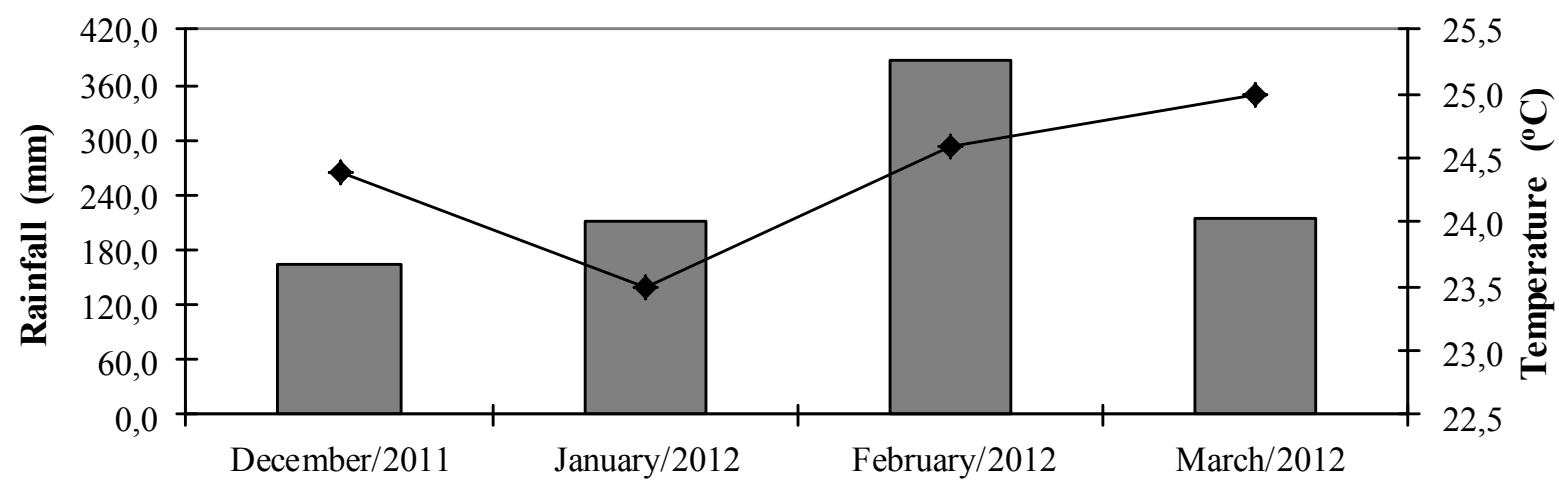

Months of the year

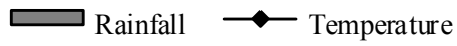

Figure 1. Rainfall and average temperatures observed during the period from December 2011 to March 2012 in Rio Verde GO.

The experimental design used was completely randomized, with four replications. The treatments consisted of corn silage, sorghum silage, silage peanuts, corn silage with $30 \%$ forage peanut, and sorghum silage with $30 \%$ peanut, totaling 20 experimental silos.

For the fodder silage, corn and sorghum were harvested separately at $20 \mathrm{~cm}$ from the ground level with a cutter rib after 110 days of growth; the corn and sorghum had an average dry matter (DM) content of $33 \%$. In addition, the peanut forage was harvested at $5 \mathrm{~cm}$ from the ground level.

The forages were minced separately in a stationary chopper to a particle size of 10 to $30 \mathrm{~mm}$. The material was homogenized prior to the addition of $30 \%$ peanut forage as an additive to the silage corn and sorghum. Next, the material was homogenized and stored in experimental PVC silos measuring $10 \mathrm{~cm}$ in diameter and $50 \mathrm{~cm}$ in length. The silos were closed with PVC lids and sealed with tape to prevent the entry of air. The silos were immediately stored at room temperature and protected from rain and sunlight.

The silos were opened after 60 days of fermentation, and the upper and lower $5 \mathrm{~cm}$ of silage were discarded from each experimental silo. The central portion of each silo was homogenized and placed in plastic trays. Part of the silage was separated for $\mathrm{pH}$, titratable acidity (TA) and buffering capacity (BC) analysis based on the methods described by Silva and Queiroz (2002).

Next, a silage sample was collected and divided into two parts. The first part was placed in plastic bags and frozen. These samples were thawed to extract the liquid portion and to measure the $\mathrm{N}$ $\mathrm{NH}_{3} / \mathrm{TN}$ (ammonia nitrogen), soluble carbohydrate (CHOsol), and organic acid contents. Organic acids were analyzed by gas chromatography based on the methods presented by Bonassi (1977) to measure the acetic, propionic, butyric, and lactic acid contents.

The other part of the silage, which weighed approximately $1 \mathrm{~kg}$, was placed in a convection oven at $55{ }^{\circ} \mathrm{C}$ for 72 hours to determine the dry matter (DM) content. Then, the samples were ground in a Willey mill with a $1-\mathrm{mm}$ sieve.

The nutrient compositions of the silages were determined by the DM, crude protein (CP), neutral detergent fiber (NDF), acid detergent fiber (ADF), hemicellulose, ether extract (EE), and mineral matter (MM) contents following the methods described by Silva and Queiroz (2002). The total digestible nutrient (TDN) contents were obtained with the equation proposed by Chandler (1990). All nutrient analyses were performed in duplicate.

To determine the in vitro digestibility of the dry matter (IVDDM), the technique described by Tilley and Terry (1963) was adapted for use with the artificial rumen developed by $\mathrm{ANKON} \AA$ and for use with the "Daisy incubator" instrument from Ankom Technology (in vitro true digestibility - IVTD). Rumen fluid was collected from two fistulated male crossbred (half Holstein and half Nellore) cattle with an average weight of $550 \mathrm{~kg}$.

Before the silage production, $0.500 \mathrm{~kg}$ of the crushed material was removed for the chemical analysis of the corn, sorghum, and forage peanut plants (Table 1), according to the methodologies described above. 
W. G. CARVALHO et al.

Table 1. Chemical compositions of the corn, sorghum and forage peanut used in the silage production.

\begin{tabular}{lccc}
\hline Chemical composition & Corn & Sorghum & Forage peanut \\
\hline DM (\%) & 33.70 & 32.80 & 19.34 \\
CHOsol (\%) & 11.50 & 10.30 & 3.53 \\
BC (Emg/100 g of DM) & 13.40 & 14.23 & 28.50 \\
CP (\%) & 9.70 & 10.50 & 20.30 \\
NDF (\%) & 11.59 & 14.15 & 46.47 \\
ADF (\%) & 7.80 & 8.56 & 39.70 \\
Hemicellulose (\%) & 3.79 & 5.59 & 6.77 \\
EE (\%) & 4.81 & 4.43 & 2.64 \\
MM (\%) & 3.45 & 3.23 & 7.80 \\
TDN (\%) & 81.67 & 80.52 & 57.50 \\
IVDDM (\%) & 87.50 & 82.40 & 68.70 \\
\hline
\end{tabular}

DM: dry matter; CHOsol; soluble carbohydrate; BC; buffering capacity; CP; crude protein; NDF; neutral detergent fiber; $\mathrm{ADF}$; acid detergent fiber; $\mathrm{EE}$; ether extract; $\mathrm{MM}$; mineral matter; TDN; total digestible nutrient; IVDDM; in vitro digestibility of the dry matter.

Data were subjected to analysis of variance, and the means were compared by Tukey's test with a $5 \%$ probability in the statistical program SISVAR 4.6 (FERREIRA, 2011).

\section{RESULTS AND DISCUSSION}

The $\mathrm{pH}, \mathrm{TA}, \mathrm{BC}, \mathrm{CHOsol}$, organic acids, $\mathrm{DM}, \mathrm{CP}, \mathrm{EE}, \mathrm{NDF}$, hemicellulose, TDN, and IVDDM values were influenced $(\mathrm{P}<0.05)$ by the silages. However, no silage significantly affected $(\mathrm{P}>0.05)$ the MM, N-NH $/ \mathrm{TN}$ and ADF contents.

Evaluating the $\mathrm{pH}$ of the silages from the different forage systems revealed that only the sorghum silage differed from the forage peanut silage, which had the highest $\mathrm{pH}$ value (Table 2). This finding potentially resulted from the high $\mathrm{BC}$ and the low CHOsol (3.24\%) contents of the forage peanut. Tosi and Oliveira (1994) reported that legumes ensiled while fresh exhibit limited fermentation due to their high $\mathrm{BC}$, which neutralizes the action of acids that are formed during fermentation.

Paulino et al. (2009) evaluated forage peanut silages with different additives and found that the highest $\mathrm{pH}$ value (5.48) was obtained for peanut silage in natura, which was greater than the $\mathrm{pH}$ value of 4.52 that was obtained here.

The final silage $\mathrm{pH}$ indicates the quality of the fermentation process and should be low enough to inhibit the growth of undesirable bacteria, such as those of the genus Clostridium (MCDONALD et al., 1991).

With the exception of the legume silage, the $\mathrm{pH}$ values were within the appropriate range, which according to McDonald et al. (1991) is 3.8 to 4.2. These results show the importance of corn and sorghum silages added with peanut forage because the annual cultures contain higher levels of MS and $\mathrm{CHOsol}$ in relation to forage peanut (Table 1).

Such intercropping yields proper fermentation, promotes a more rapid decline in silage $\mathrm{pH}$, and blocks the proteolytic enzymes from the plant (enterobacteria and Clostridium), which improves the silage quality (TOMICH et al., 2004).

Table 2. $\mathrm{pH}, \mathrm{TA}, \mathrm{BC}, \mathrm{N}-\mathrm{NH}_{3} / \mathrm{TN}$ and $\mathrm{CHOsol}$ values of the silages.

\begin{tabular}{|c|c|c|c|c|c|}
\hline Silages & $\mathbf{p H}$ & TA & $\begin{array}{c}\text { BC } \\
(\mathrm{Emg} / 100 \mathrm{~g} \text { of } \mathrm{DM})\end{array}$ & $\begin{array}{c}\mathbf{N}-\mathbf{N H}_{3} \\
(\% \mathrm{~N} \text { total })\end{array}$ & $\begin{array}{c}\text { CHOsol } \\
(\%)\end{array}$ \\
\hline Corn & $4.00 \mathrm{ab}$ & $8.37 \mathrm{a}$ & $15.70 \mathrm{c}$ & $2.90 \mathrm{c}$ & $9.25 \mathrm{a}$ \\
\hline Sorghum & $3.50 \mathrm{~b}$ & $7.75 \mathrm{a}$ & $16.58 \mathrm{c}$ & $3.18 \mathrm{c}$ & $8.25 \mathrm{a}$ \\
\hline Forage Peanut & $4.52 \mathrm{a}$ & $5.75 \mathrm{~b}$ & $33.13 \mathrm{a}$ & $6.40 \mathrm{a}$ & $3.24 \mathrm{c}$ \\
\hline Corn $+30 \%$ Forage Peanut & $4.00 \mathrm{ab}$ & $8.12 \mathrm{a}$ & $24.82 \mathrm{~b}$ & $4.61 \mathrm{~b}$ & $6.50 \mathrm{~b}$ \\
\hline Sorghum $+30 \%$ Forage Peanut & $4.00 \mathrm{ab}$ & $7.37 \mathrm{a}$ & $27.07 \mathrm{~b}$ & $4.49 \mathrm{~b}$ & $6.13 \mathrm{~b}$ \\
\hline $\mathrm{CV}(\%)$ & 8.43 & 11.65 & 12.21 & 9.48 & 11.82 \\
\hline
\end{tabular}

Means followed by lowercase letters in the columns differ according to Tukey's test $(\mathrm{P}<0.05)$.

TA: titratable acidity; $\mathrm{BC}$ : buffering capacity; $\mathrm{N}^{-\mathrm{NH}_{3}}$ : ammonia nitrogen; $\mathrm{CHOsol}$; soluble carbohydrate.

Regarding the TA, only the drying of the forage peanut differed $(\mathrm{P}<0.05)$ from the other silages with a lower value. This result may be correlated with the higher $\mathrm{pH}$ of the forage peanut silage. Silva and Queiroz (2002) reported that the TA analysis indicates the general fermentation quality of the silage, which influences the taste, odor, color, and stability of the silage because these properties are directly related to the acids that determine the $\mathrm{pH}$ (especially lactic acid).

The peanut silage had the highest $\mathrm{BC}$ value because of the higher $\mathrm{pH}$ (Table 2). The corn and 
sorghum silages added with the forage peanut were effective in lowering the $\mathrm{BC}$ values, as annual crops have a lower $\mathrm{BC}$ and participate in a greater proportion of silage $(70 \%)$.

A similar pattern was obtained for the $\mathrm{N}$ $\mathrm{NH}_{3} / \mathrm{TN}$ content (Table 2). The highest $\mathrm{N}-\mathrm{NH}_{3} / \mathrm{TN}$ content was obtained for the forage peanut, followed by corn and sorghum silages added with forage peanuts (Table 2). However, although the silage peanuts contained a higher amount of $\mathrm{N}-\mathrm{NH}_{3} / \mathrm{TN}$, the levels obtained in all silages were consistent with what is considered good-quality silage. These contents remained below $10 \%$, which indicated that the silage was of good quality in accordance with the report of Tomich et al. (2004). Furthermore, this finding indicates that the studied silages exhibited proper fermentation and that the fermentation process did not result in the excessive breakdown of proteins into ammonia (VAN SOEST, 1994).

Regarding the CHOsol content, peanut silage had the lowest value, differentiating the silage of corn and sorghum with the addition of perennial peanuts (Table 2). The added silage CHOsol provided content increments of 42.3 and $34.5 \%$, respectively, compared with silage peanuts. This increase resulted from the higher $\mathrm{CHOsol}$ content in the corn and sorghum (Table 1).

The organic acid concentration (Table 3) revealed that the corn and sorghum silages had greater lactic acid concentrations. This outcome resulted from the greater CHOsol contents in the corn and sorghum grains and explained the lower $\mathrm{pH}$ values in those treatments.

McDonald et al. (1991) reported that an appropriate $\mathrm{CHOsol}$ concentration in silage provides favorable conditions for the establishment and growth of bacteria in the genus Lactobacillus, which produce lactic acid. Lactic acid is the "strongest" of the fatty acids that are produced in the silage fermentation process and is desirable for providing rapid $\mathrm{pH}$ stabilization and preservation of the ensiled material.

Assessing the quality of silage of corn consortium with Marandu grass, Leonel et al. (2009) found that corn silage alone, silage from corn intercropped with two rows of Marandu grass, and silage from corn intercropped with broadcast Marandu grass had lactic acid concentrations of 6.35 , 7.55 , and $8.37 \%$, respectively. These values were similar to those obtained in the present study for corn silage added with forage peanuts

Table 3. Lactic, acetic, propionic, and butyric organic acid concentrations in the silages.

\begin{tabular}{|c|c|c|c|c|}
\hline Silages & $\begin{array}{c}\text { Lactic } \\
(\%)\end{array}$ & $\begin{array}{c}\text { Acetic } \\
(\%)\end{array}$ & $\begin{array}{c}\text { Propionic } \\
(\%)\end{array}$ & $\begin{array}{c}\text { Butyric } \\
(\%)\end{array}$ \\
\hline Corn & $9.51 \mathrm{a}$ & $1.49 \mathrm{c}$ & $0.09 \mathrm{c}$ & $0.02 \mathrm{c}$ \\
\hline Sorghum & $8.35 \mathrm{a}$ & $2.01 \mathrm{bc}$ & $0.10 \mathrm{c}$ & $0.04 \mathrm{bc}$ \\
\hline Forage Peanut & $3.35 \mathrm{c}$ & $5.12 \mathrm{a}$ & $0.93 \mathrm{a}$ & $0.11 \mathrm{a}$ \\
\hline Corn $+30 \%$ Forage Peanut & $6.28 \mathrm{~b}$ & $3.77 \mathrm{~b}$ & $0.36 \mathrm{~b}$ & $0.07 \mathrm{ab}$ \\
\hline Sorghum $+30 \%$ Forage Peanut & $5.67 \mathrm{~b}$ & $3.84 \mathrm{~b}$ & $0.41 \mathrm{~b}$ & $0.06 \mathrm{ab}$ \\
\hline CV $(\%)$ & 12.30 & 10.43 & 18.54 & 19.32 \\
\hline
\end{tabular}

Means followed by lowercase letters in the same columns differ according to Tukey's test $(\mathrm{P}<0.05)$

For acetic and propionic acids, the highest concentration was obtained in the silage peanuts. In addition, butyric acid showed no significant effect $(\mathrm{P}<0.05)$ between the silage forage and corn peanuts (Table 3).

The corn and sorghum silages added with peanut feed resulted in an increase of $48 \%$ and $69 \%$ lactic acid, respectively, in contrast to a reduction of $36 \%$ and $33 \% ; 158 \%$ and $127 \%$; and $57 \%$ and $83 \%$ for acetic acid, propionic acid, and butyric acid, respectively. This reduction is important because elevated acetic acid production indicates the activity of enterobacteria, according to McDonald et al. (1991). Enterobacteria are active during the initial stages of silage fermentation and compete for nutrients with lactic acid bacteria. In addition, enterobacteria show little proteolytic activity but are capable of degrading certain amino acids and contributing to the production of ammonia and biogenic amines (in the same manner as Clostridium bacteria). According to these authors, the fermentation mechanisms of enterobacteria are similar to those of heterofermentative bacteria, which result in DM and small energy losses. In this study, the concentrations of organic acids for all silages were considered sufficient for the proper conservation and stability of silage. These results show the importance of making silage from annual crops with added with legumes such as the forage peanut, due to its low content of CHOsol, low DM at the time of cutting, and high $\mathrm{BC}$, thus balancing the silage quality.

Evaluating the DM, it can be seen in Table 4 that the lowest content was obtained in silage peanuts. The addition of forage peanuts as an additive in the corn and sorghum silages helped to increase the DM content of the silages. Furthermore, the addition of annual cultures served as moisture absorbers of the silage feed peanuts, which was effective in absorbing water inside the silo, improving the fermentation process, and checking the silage quality. The unique corn and sorghum 
silages supplemented with peanut had DM contents within the optimal range, ranging from $25 \%$ to $32 \%$. Cheeke (1999) reported that DM contents should be

Table 4. DM, CP, EE and MM contents of the silages. between $25 \%$ and $35 \%$ to ensure the production of good-quality silage.

\begin{tabular}{|c|c|c|c|c|}
\hline Silages & DM (\%) & CP (\%) & $\operatorname{EE}(\%)$ & MM (\%) \\
\hline Corn & $31.25 \mathrm{a}$ & $7.15 \mathrm{c}$ & $4.56 \mathrm{a}$ & $2.07 \mathrm{a}$ \\
\hline Sorghum & $31.57 \mathrm{a}$ & $6.07 \mathrm{c}$ & $4.41 \mathrm{a}$ & $2.20 \mathrm{a}$ \\
\hline Forage Peanut & $19.25 \mathrm{c}$ & $18.61 \mathrm{a}$ & $2.16 \mathrm{~b}$ & $1.95 \mathrm{a}$ \\
\hline Corn $+30 \%$ Forage Peanut & $25.27 \mathrm{~b}$ & $11.45 \mathrm{~b}$ & $3.15 \mathrm{ab}$ & $2.11 \mathrm{a}$ \\
\hline Sorghum $+30 \%$ Forage Peanut & $26.77 \mathrm{~b}$ & $10.36 \mathrm{~b}$ & $3.03 \mathrm{ab}$ & $1.82 \mathrm{a}$ \\
\hline $\mathrm{CV}(\%)$ & 3.41 & 12.53 & 17.46 & 14.19 \\
\hline
\end{tabular}

Means followed by lowercase letters in the same columns differ according to Tukey's test $(\mathrm{P}<0.05)$.

DM: dry matter; CP; crude protein; EE; ether extract; MM; mineral matter.

There was a variation in the CP content of the silage. The peanut silage had the highest CP content, differing $(\mathrm{P}<0.05)$ from the corn and sorghum silages with the unique addition of perennial peanuts (Table 4). Due to the low CP content of annual crops, the addition of forage peanuts to the corn and sorghum silages helped to increase the $\mathrm{CP}$ content by $60 \%$ and $70 \%$, respectively, compared with the corn silage and sorghum alone. Adding forage peanuts to the silage improves the quality of the grass silage and restricts Clostridium activity, preserving the protein fraction. In this sense, the association of silage grasses with legumes becomes advantageous as a technique to improve the $\mathrm{CP}$ contents of corn silage and sorghum. The results obtained in this study are relevant to improving the quality of silage because these values are above the $7 \%$ rate (VAN SOEST, 1994), which is desirable for the proper functioning of the food in the rumen.

Paulino et al. (2009) evaluated peanut silage in natura and with different additives. These authors found a CP content of $21.60 \%$ for peanuts in natura. This content was greater than the content obtained here for the forage peanut silage.

The corn and sorghum silages had the highest EE values (Table 4), followed by the silages added with forage peanuts. The association of crops helps to balance the energy value of silage, which is important in ruminal fermentation, fiber digestibility, and the pass rate (NRC, 2001). The lowest EE value was obtained for the forge peanut silage $(2.16 \%)$. These results were similar to the results obtained by Paulino et al. (2009), who evaluated the chemicalnutrient characteristics of forage peanut silages and found $\mathrm{EE}$ contents of $2.05 \%$ for in natura silage.

No significant differences $(\mathrm{P}<0.05)$ in $\mathrm{MM}$ were observed among the different silages (Table 4). Relative to this study, greater MM values were obtained by Alfaya et al. (2009), who evaluated corn silage and found average MM contents of $2.3 \%$. However, the MM content only indicates the amount of minerals present in the sample. High values of ash may also result from a high silica content, which is not useful for animals (HOFFMAN, 2005).

Regarding the NDF, the highest value was obtained in silage peanuts. While there was no significant effect $(\mathrm{P}>0.05)$, the silages of corn and sorghum added with forage peanuts helped to reduce the NDF by $11 \%$ and $10.83 \%$, respectively, compared with silage exclusively consisting of the peanut, presenting a lower fiber content and thereby diluting the fiber occurring in the silage and reducing the values. This reduction is considered positive because this cell wall component is inversely correlated with DM intake (VAN SOEST, 1994). Lima et al. (2002) reported that NDF content is an important parameter for defining forage quality. Fibrous foods remain in the rumen longer and limit the intake rate. Specifically, NDF contents of more than $60 \%$ are negatively correlated with forage intake.

However, for the ADF content, there was no significant effect $(\mathrm{P}<0.05)$ among the silages (Table 5 ), with contents remaining between $25.32 \%$ and $32.97 \%$. These contents are within the acceptable range. Nussio et al. (1998) reported that tropical forages with ADF contents of approximately $40 \%$ or more had low intake and digestibility.

Regarding the hemicellulose content, Table 5 indicates that the corn silage presented the highest value $(\mathrm{P}<0.05)$, differing from the addition of forage peanut silage and added. According to Hunt et al. (1993), hemicellulose appears to be the primary substrate for fermentation after CHOsol. In addition, $50 \%$ of the total organic matter originally present may be degraded.

Only the silage peanut differed $(\mathrm{P}<0.05)$ in NDT content from the other silages with lower value (Table 5). Once again, it is worth emphasizing the importance of making the corn silage and sorghum added with forage peanuts, which helped to increase the TDN levels by $16.02 \%$ and $14.21 \%$, respectively, compared with silage made exclusively from forage peanut. 
W. G. CARVALHO et al.

Table 5. NDF, ADF, hemicellulose, TDN and IVDDM contents of the silages.

\begin{tabular}{|c|c|c|c|c|c|}
\hline Silages & $\begin{array}{c}\text { NDF } \\
(\%)\end{array}$ & $\begin{array}{l}\text { ADF } \\
(\%)\end{array}$ & $\begin{array}{c}\text { Hemic. } \\
(\%)\end{array}$ & $\begin{array}{l}\text { TDN } \\
(\%)\end{array}$ & $\begin{array}{c}\text { IVDDM } \\
(\%)\end{array}$ \\
\hline Corn & $42.38 \mathrm{~b}$ & $25.32 \mathrm{a}$ & $32.56 \mathrm{a}$ & $67.15 \mathrm{a}$ & $78.25 \mathrm{a}$ \\
\hline Sorghum & $45.14 \mathrm{~b}$ & $25.71 \mathrm{a}$ & $24.93 \mathrm{ab}$ & $65.84 \mathrm{a}$ & $72.50 \mathrm{ab}$ \\
\hline Forage Peanut & $52.46 \mathrm{a}$ & $32.97 \mathrm{a}$ & $19.50 \mathrm{~b}$ & $54.96 \mathrm{~b}$ & $67.50 \mathrm{~b}$ \\
\hline Corn $+30 \%$ Forage Peanut & $47.26 \mathrm{ab}$ & $28.27 \mathrm{a}$ & $18.99 \mathrm{~b}$ & $63.79 \mathrm{a}$ & $69.13 \mathrm{~b}$ \\
\hline Sorghum $+30 \%$ Forage Peanut & $47.33 \mathrm{ab}$ & $30.79 \mathrm{a}$ & $16.53 \mathrm{~b}$ & $62.77 \mathrm{a}$ & $68.30 \mathrm{~b}$ \\
\hline $\mathrm{CV}(\%)$ & 5.52 & 12.30 & 18.69 & 5.01 & 4.37 \\
\hline
\end{tabular}

Means followed by lowercase letters in the same columns differ according to Tukey's test $(\mathrm{P}<0.05)$.

NDF; neutral detergent fiber; ADF; acid detergent fiber; Hemic.: hemicellulose; TDN; total digestible nutrient; IVDDM; in vitro digestibility of the dry matter.

These results are most likely due to the higher TDN content (Table 1) in the corn and sorghum grains. In addition, the chemical-nutrient characteristics of these crops can increase parameters that are directly related to energy increases, such as EE, lipids, and non-fibrous carbohydrates, while reducing parameters that have an inverse relationship, such as NDF and ADF (RIBEIRO et al., 2008).

The corn and sorghum silages had the highest IVDDM (Table 5). These results are most likely correlated with the low fiber contents in these crops (Table 1), which contributed to greater silage digestibility. This increase in digestibility is most likely associated with changes in the chemical composition of IVDDM with decreased NDF, ADF and hemicellulose contents, which would provide readily digestible carbohydrates for rumen microorganisms. Van Soest (1994) explained that the IVDDM value increases with the addition of concentrate because of the increase in non-structural carbohydrates, which are more digestible than structural carbohydrates.

The IVDMD values of unique corn silage were similar to those obtained by Domingues et al. (2012), who evaluated different silages of various corn hybrids (second harvest crops) and found mean digestibility levels of $70.79 \%$.

\section{CONCLUSIONS}

The silages of corn and sorghum added with peanut helped to improve the silage fermentative and bromatological characteristics, proving to be an efficient technique for improving silage quality.

The forage peanut silage had lower fermentative characteristics than the corn and sorghum silages. However, the forage peanut silage had a greater CP content, which increased the protein contents of the corn and sorghum silages when added with forage peanuts.

\section{REFERENCES}

ALFAYA, H. et al. Avaliação de silagens elaboradas com milho produzido sob dois níveis de adubação:
II. Qualidade. Pesquisa Agropecuária Gaúcha, Porto Alegre, v. 15, n. 2, p. 123-133, 2009.

BONASSI, I. A. Determinação de ácidos orgânicos em silagens por meio de cromatografia gasosa. 1977. 40 p. Dissertação (Mestrado em Zootecnia) Universidade Estadual Paulista, Jaboticabal, 1977.

CARDOSO, R. M. et al. Avaliação de híbridos de sorgo para silagem por meio da degradabilidade in situ. Revista Brasileira de Milho e Sorgo, Sete Lagoas, v. 11, n. 1, p. 106-114, 2012.

CHANDLER, P. Energy prediction of feeds by forage testing explorer. Feedstuffs, Minneapolis, v. 62 , p. 12,1990 .

CHEEKE, P. R. Applied animal nutrition: feeds and feeding. 2. ed. New Jersey, USA: Prentice-Hall, $1999.525 \mathrm{p}$.

DOMINGUES, A. N. et al. Nutrition value of silage from corn hybrids in the State of Mato Grosso, Brazil. Acta Scientiarum. Animal Sciences, Maringá, v.3 4, n. 2, p.117-122, 2012.

FERREIRA, D. F. Sisvar: a computer statistical analysis system. Ciência e Agrotecnologia, Lavras, v. 35, n. 6, p. 1039-1042, 2011.

GARCIA, C. M. P. et al. Desempenho agronômico da cultura do milho e espécies forrageiras em sistema de Integração Lavoura-Pecuária no Cerrado. Ciência Rural, Santa Maria, v. 43, n. 4, p. 589-595, 2013.

HOFFMAN, P. Ash content of forages. Focus on Forage, Madison, v 7, n. 1 p.1-2, 2005.

HUNT, C. W. et al. Effects of hybrid and ensiling with and without a microbial inoculant on the nutritional characteristics of whole-plant corn. Journal Animal Science, Champaign, v. 71, n. 1, p. 38-43, 1993.

LEONEL, F. P. L. et al. Consórcio capim-braquiária e milho: comportamento produtivo das culturas e características nutricionais e qualitativas das 
silagens. Revista Brasileira de Zootecnia, Viçosa, v. 38 , n. 1, p. 166-176, 2009.

LIMA, L. G. et al. Fontes de amido e proteína para vacas leiteiras em dietas à base de capim-elefante. Scientia Agricola, Piracicaba, v. 59, n. 1, p. 19-27, 2002.

McDONALD, P.; HENDERSON, A. R.; HERON, S. J. E. The biochemistry of silage. 2. ed. Marlow: Chalcombe Publicatons, 1991. 340 p

NRC (NATIONAL RESEARCH COUNCIL), Nutrient requirements of beef cattle 7th. Washington: National Academy Press, 2001 p. 93.

NUSSIO, L. G.; MANZANO, R. P.; PEDREIRA, C. G. S. Valor alimentício em plantas do gênero Cynodon. In: SIMPÓSIO SOBRE MANEJO DA PASAGEM, 15, 1998, Piracicaba. Anais... Piracicaba: FEALQ/ESALQ, 1998. p. 203-242.

OLIVEIRA, L.B. et al. Perdas e valor nutritivo de silagens de milho, sorgo Sudão, sorgo forrageiro e girassol. Revista Brasileira de Zootecnia, Viçosa, v. 39, n. 1, p. 61-67, 2010.

PAULINO, V. T. et al. Silagem de amendoim forrageiro (Arachis pintoi cv. Belmonte) com diferentes aditivos. Boletim de Indústria Animal, Nova Odessa, v. 66, n. 1, p. 33-43, 2009.

PINTO, R. S. et al. Qualidade da silagem de grãos úmidos de diferentes forrageiras. Global Science and Technology, Rio Verde, v. 5, n. 3, p. 124-136, 2012.

RIBEIRO, X.R.R. et al. Capim-tanzânia ensilado com níveis de farelo de trigo. Revista Brasileira de Saúde e Produção Animal, Salvador, v. 9, n. 4, p. 631-640, 2008.

SANTOS, J. P. et al. Consórcio sorgo-soja. XIII. Efeito de sistema de corte e arranjo de plantas no desempenho forrageiro do sorgo. Ciência e Agrotecnologia, Lavras, v. 33, n. 2, p. 397-404, 2009.

SILVA, D. J; QUEIROZ, A. C. Análise de alimentos: métodos químicos e biológicos. 3. ed. Viçosa, MG: UFV, 2002. 235 p.

TILLEY, J. M. A.; TERRY, R. A. A two stage technique for in vitro digestion of forages crops. Journal of the British Grassland Society, Oxford, v. 18, n. 2 , p. 104-111, 1963.

TOMICH, T. R. et al. Potencial forrageiro de híbridos de sorgo com capim-sudão Arquivos Brasileiros de Medicina Veterinária e Zootecnia,
Belo Horizonte, v. 56, n. 2, p. 258-263, 2004.

TOSI, H.; OLIVEIRA, M. D. S. Avaliação da ensilagem de alfafa sob diferentes tratamentos. Revista Brasileira de Zootecnia, Viçosa, v. 23, n. 2, p. 305-310, 1994.

VAN SOEST, P. J. Nutritional ecology of the ruminant. 2 ed. Ithaca: Cornell, 1994. 476 p. 